\title{
Durkheim, Vygotsky and the Curriculum of the Future [1]
}

\author{
MICHAEL F. D. YOUNG \\ Institute of Education, University of London, UK
}

ABSTRACT This paper is concerned with the principles on which the curriculum should be based. It argues that the fundamental issue is the relationship between the knowledge on which the curriculum is based and the everyday knowledge that learners bring to school or college. The approaches to knowledge of two educational theorists, the French sociologist, Emile Durkheim, and the Russian psychologist, Lev Vygotsky, are discussed. While pointing out some of the limitations of their approaches, the paper argues that their attempts to integrate the objectivity and the historicity of knowledge must remain at the heart of future curriculum debates.

Only the church has an art. It alone gives us a little comfort and detaches us from the world ... we are all children beside the liturgists and theologians ... the greatest ... imitate them. (Paul Valery, 1891)

... the rules of classic art teach us by their arbitrary nature that the thoughts arising from our daily needs, sentiments and experiences are only a small part of the thoughts of which we are capable. (Paul Valery, 1941)

\section{Introduction}

What principles should underpin the curriculum of the future? Firstly, will it continue to be based on a clear separation between the knowledge to be acquired at school and the knowledge that people acquire in their everyday lives? And secondly, will it continue to take the disciplinary form that became established during the 19th century, or will greater emphasis be placed on the practical and social skills and knowledge that adults are likely to need in a competitive global economy? Answers to these questions will depend, at least in part, on the assumptions that are made about the nature of knowledge, and how the knowledge on which the curriculum is based is assumed to differ from the 'everyday' knowledge of communities and workplaces.

The belief that knowledge acquired through the curriculum is cognitively superior to people's everyday knowledge has been the major rationale for the extension of formal education throughout the last century, and for the reform of vocational programmes that had previously relied only on workplace learning. However, criticisms of the traditional curriculum have become increasingly influential in the last decade. A growing tension has 
become apparent between the fluidity and openness to innovation of successful advanced economies - what some have termed 'fast capitalism' - and the persistence of relatively rigid divisions between the different school subjects and disciplines and between curriculum knowledge in general, and the knowledge that people use in employment and more generally in their adult lives. On the one hand it seems inconceivable that the curriculum could be immune from changes in society and from what some argue are changes in the mode and sites of the production of knowledge (Gibbons et al., 1994). On the other hand, a disciplinary curriculum separated from everyday knowledge is an almost universal feature of education systems and has been the basis of the massive expansion of knowledge and the associated economic changes of the last one hundred and fifty years.

Muller (2000) sharpens the dilemma facing curriculum designers by characterising this tension between 'past' and possible 'future' curricula in terms of the contrasting principles of 'insularity' and 'hybridity'. The principle of insularity emphasises the differences rather than the continuity between types of knowledge. It rejects the assumption that the divisions and classifications between types of knowledge are just a reflection of traditions inherited from the past and little more than a justification of existing professional interests and power relations. These classifications have, it is claimed, both epistemological and pedagogic rationales; in other words they relate in fundamental ways to how people learn and how they produce new knowledge. It follows that the continued production and acquisition of new knowledge put limits on the possibilities for curriculum innovation: in particular the scope for crossing disciplinary and subject boundaries and integrating theoretical knowledge with practical 'know-how' and skills. Not surprisingly, the principle of insularity can be invoked to support profoundly conservative doctrines in defence of the curriculum status quo. However the argument in support of insularity is not just political. It is based on a view that knowledge is, at least in some sense, beyond history and society. As Descartes expressed it nearly four centuries ago, real knowledge is beyond 'all custom and example'.

The principle of hybridity, on the other hand rejects any claim that the boundaries and classifications of the curriculum reflect features of knowledge itself and are anything more than a product of history. It stresses the essential unity and continuity of forms and kinds of knowledge ... (and) the permeability of classificatory boundaries (Muller, 2000) (my italics). The principle of hybridity is defended not on pedagogic or epistemological grounds [2], but in terms of its consistency with what is seen as the increasingly 'boundary-less' character of modern economies (Reich, 1991). Such a 'social constructivist' view of knowledge has always appealed to radicals as a basis for exposing the vested interests associated with existing boundaries and their claims to universality. It is such arguments that are endorsed by post modernists who invoke Nietszche and argue that hybridity is only superficially a new idea; for them neither epistemological nor pedagogic criteria have ever been more than a way of masking issues of power and interest.

There are, however, practical reasons why a curriculum based on the principle of hybridity has begun to appeal to education policy makers: it appears to converge with the new policy goals of social inclusion and accountability. Whereas pressures for social inclusion require the curriculum to go 'beyond its boundaries' and recognise the knowledge and experience of those traditionally excluded from formal education, pressures for greater accountability call into question the autonomy of the specialist knowledge producers. In both cases social and economic arguments for a 'responsive' curriculum that can be the basis for new kinds of skills and knowledge that transcend current disciplinary boundaries and academic/vocational divisions are set against the insularity of the traditional academic curriculum. In rejecting any link between specific knowledge classifications and either pedagogic requirements or epistemological principles, the hybridity principle supports the 
belief that decisions about the curriculum depend, ultimately, on market pressures and political priorities.

This paper is concerned is to find a basis for the curriculum that avoids both the ahistorical conservativism of traditional insularity and the uncertain consequences of hybridity and its ultimate renunciation of any distinctive pedagogic or epistemological criteria. In order to do this it discusses and compares some aspects of the social and educational theories of the French sociologist Emile Durkheim and the Russian psychologist, Lev Vygotsky. Both theorists, albeit in different ways, gave priority to the differentiation of knowledge, especially the differences between theoretical and everyday knowledge, rather than to its unity. However, unlike many to defend the principles of insularity, both writers tried to locate the differentiation of knowledge within a social theory.

Section 2 describes the theoretical basis of the idea of insularity in the writings of Emile Durkheim (1961) and, in particular, his distinctions between 'sacred' and 'profane' orders of meaning. Section 3 compares Durkheim and Vygotsky's social theories of knowledge and the different ways in which they drew on ethnographies of primitive societies to lay the basis for a social theory of thought (and knowledge). Section 4 examines the parallels between Vygotsky's distinction between scientific and everyday concepts and Durkheim's distinction between the 'sacred' and 'profane'. Section 5 interprets Vygotsky's distinction dialectically, in terms of his overall theory of human development. Potentially such an approach offers a way of going beyond Durkheim, by locating knowledge and the curriculum within a broader theory of social change. However, I shall suggest that although Vygotsky avoids Durkheim's ahistoricism, a dialectical approach introduces new problems that it is, on its own, unable to resolve. By locating it in the history of man's actions in making sense of and transforming the external world, knowledge, as distinct category that refers to causes and explanations that are not tied to specific purposes, disappears [3]. Understandably most Soviet theorists of Vygotsky's time claimed that Marx's theory of the historical role of the working class had 'solved' the problem of knowledge. Vygotsky's successors in the West have tried to avoid this Marxist dogmatism as well as the relativist implications of a dialectical approach by retaining the universality of the principle of contradiction, but generalising it from social class relations to social life in general. This approach has parallels with Dewey, who endorsed a non-dogmatic version of the dialectical method but relied on his belief in science and the progressive democratisation of American society as criteria for knowledge and truth (Rytina \& Loomis, 1970). I conclude that on its own, a dialectical approach to knowledge is inadequate as a basis for a curriculum of the future and suggest that it is necessary to combine a historical view of knowledge with what I refer to as a 'social realist' concept of its objectivity.

In attempting to address the unresolved problems of a dialectical approach, I turn briefly in Section 6 to Durkheim's lectures on pragmatism (Durkheim, 1983). I argue that his idea of a concept of knowledge that has some independence from the contexts of its production and development in history is necessary both as a basis for the curriculum and in accounting for the unprecedented growth of knowledge since the 17 th century. Secondly, I argue that such a concept of knowledge need not be ahistorical; knowledge has emerged as the product of the codes, rules and practices of those involved in specialist fields of enquiry and the debates about knowledge that have developed within them (Collins, 1998). The paper concludes with some observations on the questions about the curriculum with which I began.

\section{Durkheim, Knowledge and the Curriculum}

Durkheim did not develop his approach to knowledge as an explicit part of his educational theory and it is only relatively recently, thanks largely to the work of Basil Bernstein [4], that its importance for debates about the curriculum has been recognised. Developing a sociology 
of knowledge had two purposes for Durkheim. First, it was part of his broader concern to establish the distinctive role of sociology as a science of universal applicability. Secondly he wanted to establish a sound (and therefore, for him, necessarily sociological) basis for science and truth which would overcome what he saw as the fundamental weaknesses of the philosophy of his time-and its domination by rationalism and empiricism (Ward, 1996). There are at least two possible reasons for the relative neglect of Durkheim's sociology of knowledge by curriculum theorists. One may have been that his focus was not on specific fields of knowledge, such as the natural or social sciences, or the humanities, but on providing a sociological theory of knowledge in general (see Young 1971, chp. 1). Secondly, Durkheim's social theory of knowledge was not, like his study of suicide, based on contemporary data, but on extrapolating from an analysis of ethnographic studies of religion in societies that had no institutions of formal education.

Durkheim's starting point, in The Elementary Forms of Religious Life (Durkheim, 1961), was the social reality of religion, which he saw as an example of what he referred to as "collective representations'. Collective representations for Durkheim grow out of communities. They include the most basic categories of human thought, such as causality, time, and place. Furthermore, he argued that these collective representations, though initially religious in content, were the paradigm of all advanced forms of theoretical knowledge. Crucial to his account of religion and the emergence of collective representations was his distinction between 'profane' and 'sacred' orders of meaning, which he argued was a distinct feature of all the primitive societies that he studied [5].

In all the history of human thought there exists no other example of two categories of things so profoundly differentiated or so radically opposed to one another. (Durkheim, 1961, p. 53)

For Durkheim, the 'profane' referred to how people respond to their everyday world —in practical, immediate and particular ways. He distinguished this 'profane' everyday world from the 'sacred' world of religion which he saw as invented, arbitrary (in the sense of not being tied to specific objects and events) and, crucially, collective. The 'sacred' consisted of systems of related but unobservable concepts. In not being tied to specific observations or experiences, these systems of concepts had, for Durkheim, an objectivity that arose from their shared social character, and the fact that they were external to the perceptions of individuals. Because it was not individual in origin, the sacred was relatively fixed. Furthermore, in its externality to individuals, the sacred exhibited, in form although not necessarily in content, a distinctive feature of truth-individuals feel under pressure to accept it.

Religion was important for Durkheim as an example of shared collective representations, not as evidence for the existence of God. He saw that it had an integrative function [6] in maintaining social solidarity, and was a model for all the other types of abstract thought, including modern science, that consist of unobservable concepts. In other words, the totems of the aborigines and the gas laws of the physicist were, in form at least, identical for Durkheim. He identified two key features of the 'sacred', which gave it its paradigmatic status as the basis of future knowledge. First, in so far as the 'sacred' was constituted by a set of concepts shared by a community but not tied to specific objects or events, it enabled people to make connections between objects and events that, on the basis of their everyday experience, did not necessarily appear related. This 'connecting' capability is crucial for scientists and modern man in general, but no less so for those in primitive communities who experienced most natural events as external forces over which they had little control. Second, being not tied to the everyday world, the 'sacred' enables people to project beyond the present to a future. Whereas in the case of primitive societies projection referred to people's 
capacity to envisage some kind of 'after life' beyond their everyday world, in modern societies, projection becomes the potential to predict on the basis of scientific concepts and more generally to be able to conceive of alternatives. For Durkheim both these features distinguished 'theoretical' knowledge (in the sense of knowledge constituted by a system of concepts), whether religious or scientific, from everyday knowledge. At the same time the distinction was not a judgement about one type of knowledge being superior to the other; his stress was on their differences. As he pointed out, everyday living would not be possible if we could only rely on theoretical knowledge. Similarly, if our thinking was restricted to the 'profane' or the everyday it would only be possible to make sense of the world in very limited ways. Furthermore, everyday thinking, located as it is in people's responses to specific contexts, is no basis for developing objective knowledge of the world that transcends such contexts. Durkheim's argument was that all societies are characterised by a degree of specialisation between these two types of knowledge. What distinguishes societies is not specialisation per se or the availability of abstract unobservable concepts, but the extent of specialisation, the nature of the concepts [7] and the extent to which they are criticised and subjected to empirical test.

Gellner (1992) argues that the significance of Durkheim's sociology of knowledge is that it makes a powerful case for the social (as opposed to the individual) origins of abstract thought; hence Durkheim broke with the individualism of Descartes and what he saw as the abstract idealism of Hegel. Abstract or theoretical thought is not, for Durkheim, a characteristic or capacity of particular individuals but a feature of societies - all societies [8]. In showing how the features of abstract thought, especially its scope and its systematic character are related to its origins in social activities, Durkheim's sociology of knowledge is synchronic - it sees knowledge as collective representations which are developed when people come together in societies. Where his theory is less adequate is in providing a diachronic account of the differentiation and expansion of knowledge over time and the progressive extension of its association with empirical methods and specialist forms of critical analysis. Another problem with Durkheim's account is that he gives little attention to the internal stratification of knowledge within societies [9]. It seems likely that this neglect of the stratification of knowledge was, as suggested earlier, partly a result of the dependence of Durkheim's sociology of knowledge on studies of small-scale societies, with little stratification. The problem to which extrapolating from studies of primitive societies leads is that Durkheim's sociology of knowledge avoids the extent to which relations of power shape relations between types of knowledge and convert them into hierarchies (Young, 1998). Furthermore his emphasis on differences between types of knowledge in the societies that he studied neglects the tendency in modern societies for the profane knowledge of some to claim 'sacred' status. It is this neglect of the link between power and knowledge which some radical and post modernist critics of Durkheim have highlighted. However, in their critiques, they themselves tend to reduce discussions of knowledge to questions of power and neglect the very questions about knowledge with which Durkheim was concerned (Moore \& Young, 2001).

A further problem with Durkheim's social theory of knowledge is that, while an evolutionary view of the development of knowledge is implied, he says little about the process. His theory is strong in account of the social origins of different types of knowledge in the separation of sacred and profane orders of meaning; however, it says little about how one type of knowledge or unobservable concept (for example, force as a mystical ideasuch as a totem) evolves into another (such as force as a scientific idea-like gravity). Like most intellectuals of his time, Durkheim took the natural sciences for granted as the model of knowledge and did not distinguish between them and other forms of knowledge. What remains important about his view of knowledge and science was his emphasis on its 
conceptual rather than its empirical basis and his demonstration that this conceptual basis has social origins.

In searching for a more historical and dynamic approach to knowledge that can take account of the impact of societal change on the knowledge base of the curriculum, I shall contrast Durkheim's approach with the ideas of the Russian psychologist and social theorist, Lev Vygotsky. The distinction between scientific (or theoretical) and common sense thinking was, as with Durkheim, at the centre of Vygotsky's social and educational theory. However the differences as well as the similarities between the two theorists are important and in particular how these differences are linked to the way each interpreted the social origins of knowledge and science.

\section{The Social Origins of Knowledge in Vygotsky and Durkheim}

The distinction between scientific and everyday concepts was integral to Vygotsky's theory of human development and had significant similarities to Durkheim's distinction between the sacred and the profane [10]. However, although Vygotsky was undoubtedly familiar with Durkheim's work[11], I have found very few explicit references to Durkheim in his writings that have been translated into English [12]. The key section on scientific and everyday concepts in his Collected Works makes many references to Piaget's distinction between spontaneous and scientific concepts but does not explicitly refer to Durkheim [13].

Vygotsky differed from Durkheim in always retaining a focus on human development not society. He wanted to show that:

relations between mankind and nature are not all that have changed. Man himself has changed and developed. Human nature has changed in the course of history. (Luria \& Vygotsky, 1992, p. 41) (my addition in italics)

It was this concern to avoid an essentialist and a-historical view of human nature that led to Vygotsky being interested in the historical development of the human psyche and why he turned to studies of 'so-called' primitive peoples, and in particular the work of LevyBruhl. Vygotsky drew two important lessons from Levy-Bruhl-his argument for a nonindividualist theory of thought and his premise that 'different types of society are associated with different types of human psychology' (p. 44). Vygotsky points out that, for Levy Bruhl,

the higher psychological functions of primitive man are profoundly different from those same functions in civilised man ... the very type of thinking ... (is) ... a historical variable. (Luria \& Vygotsky, 1992, p. 44)

Vygotsky also noted that Levy Bruhl neglected the practical (or in Marxist terms, the productive) side of primitive societies. Unlike Levy-Bruhl, Vygotsky's view was that even primitive man was capable of

objective logical thinking whenever the purpose of his actions is direct adaptation to nature. (Luria \& Vygotsky, 1992, p. 45) (my italics)

Vygotsky did not reject Levy Bruhl's distinction between primitive and modern thought which he saw as the basis for the idea that human thought varies between societies and develops over time. However, he appears to have identified the devel- 
opmental potential of primitive thought with those 'actions in direct adaptation to nature' that Levy Bruhl himself paid little attention to.

Vygotsky does not seem, at least explicitly, to have been aware of Durkheim's quite different analysis of primitive mentality. According to Horton (1974),

Levy Bruhl sees 'primitive' and 'modern' thought as antithetical ... whereas Durkheim ... sees 'primitive' and 'modern' as two stages in a single evolutionary process ... (p. 267).

We have therefore three different approaches to the social origins of knowledge. Levy Bruhl saw the thinking of primitive man as characterised by a combination of mysticism and common sense. For him, in the process of civilisation, societies have gradually dispensed with mysticism and replaced it with the empirical methods of science-for him a superior form of common sense. Vygotsky agreed with Levy Bruhl about primitive thought being a combination of the practical and the mystical, however he gave much more emphasis to the practical, especially

the invention of tools, hunting, animal husbandry, agriculture and fighting all (of which) demand from him real and not just apparent logical thought. (Luria \& Vygotsky, 1992, p. 45)

Thus, Vygotsky located both the origins and the development of man's psyche in human labour. The development of knowledge, for Vygotsky, grew out of human labour as part of human development in general. Vygotsky did not appear to address exactly how scientific forms of thought developed from people's early struggles for survival.

Durkheim on the other hand, interpreted the findings of the ethnographies of primitive societies very differently from Levy Bruhl and Vygotsky. First, as Horton (Horton, 1974) points out, he stressed (a) the continuity between primitive religious classifications and the classifications of the sciences, and (b) the difference in modern societies between technical/practical and scientific classifications. Although he does not say so explicitly, Vygotsky would, one assumes, have rejected each of these propositions. He would have agreed with Levy Bruhl that science is not in continuity with religion but is its antithesis. Furthermore he would have rejected Durkheim's distinction between the technical and the scientific. Second, Durkheim differed from Levy Bruhl in his characterisation of primitive thought; for him the point was not just that it consisted of common sense practical thinking and mystical thinking, but that common sense (the profane) and mystical or conceptual thinking (the sacred) were separate and different. It was the shared and therefore social character of mystical thought (the sacred in Durkheim's terms) and its separateness from everyday life, not its content, that gave it objectivity and enabled it to be the basis for science.

In contrast to Durkheim, it was in primitive man's practical activity that Vygotsky saw the 'germ' of knowledge that develops later into 'scientific' concepts. For Durkheim, on the other hand, the germ of modern science is to be found not in man's practical activities but in the socially based objectivity of the religion of primitive societies. These differences between Durkheim and Vygotsky lie at the heart of their different approaches to knowledge. For the former the objectivity of knowledge is conceptual and located socially, originally in religion. For the latter, it is also located socially, but in man's productive activities in history. I will return to this point later. The next section turns to a more specific comparison of Durkheim and Vygotsky's central distinctions. 


\section{Scientific and Everyday Knowledge; Vygotsky and Durkheim's Approaches Contrasted}

Vygotsky identifies a number of features that distinguish scientific and everyday concepts. Each can be contrasted with Durkheim's distinction between the sacred and the profane.

- They involve different relationships to objects. For Vygotsky, whereas a child's relationships to the world through his or her everyday concepts is through what he or she sees or experiences directly, with scientific concepts the relationship is mediated by these concepts and is not dependent on direct experience [14].

- Scientific concepts are systematic (they depend for their meaning on their interrelationships)

Both these features are expressed in almost identical ways by Durkheim in his discussion of the differences between 'sacred' and 'profane' orders of meaning.

- For Vygotsky a child (it could of course be an adult) uses everyday concepts while not being aware of doing so, whereas reflexive awareness is (or should be) always a feature of the use of scientific concepts. Vygotsky draws a parallel with grammar, when he points out that anyone can use grammar to make sentences without knowing any grammatical rules [15]. There is a problem here, which has led to much debate among post-Vygotskians; his definition seems to refer to use as well as content. Is any concept scientific when it is used reflexively or are some concepts scientific even when not used reflexively? There is not the same explicit concern with reflexivity and awareness in Durkheim, although when he writes of the sacred being the basis of a

faculty for idealising ... substituting for the real world another different one, to which (people can) transport themselves by thought ... (through which) something is added to and above the real. (Durkheim, 1961, p. 469)

Durkheim is, I would suggest, making a similar point to Vygotsky.

Vygotsky also emphasises the inter-relatedness of the two types of concept in the following terms:

The rudiments of systematisation first enter the child's mind by way of his contact with scientific concepts and are then transferred to everyday concepts, changing their psychological structure from the top down. (Vygotsky, 1962, p. 93)

This interrelatedness of the two types of concept underlies for Vygotsky the inseparableness of learning from instruction and is a proposition that is crucial both for the curriculum and for educational research. He argues that the two kinds of concepts develop in opposite directions:

the development of a child's spontaneous concepts proceeds upwards and the development of his scientific concepts downward. (Vygotsky, 1962, p. 108)

Whereas scientific concepts begin with their verbal definition and develop 'as they are filled with further schoolwork and reading', spontaneous concepts are already 'rich in experience' but, because they are not part of a system, they provide 'no explanations and can lead to confusions' (Vygotsky, 1962, p. 108). 
As Vygotsky points out, these differences relate to the different ways in which individuals acquire the two types of concepts. In the case of everyday concepts, this is usually in face-toface meetings in concrete situations whereas acquiring scientific concepts involves a 'mediated attitude towards the object'. In considering the relationships between the two types of concepts, we confront the biggest differences between Vygotsky and Durkheim. For Vygotsky, inter-relationships between the two types were crucial-in a sense they are the process of learning. For Durkheim, who was more concerned with social order than social development or learning, it was the differences between the two types that were crucial. I referred earlier to his comment, that:

there exists no other example of two categories of things so profoundly differentiated or so radically opposed. (Durkheim, 1961, p. 53)

He goes on to say:

This is not equivalent to saying that a being can never pass from one of these worlds into another; but the manner in which this passage is effected ... demonstrates the essential duality of the kingdoms. (Durkheim, 1961, p. 54)

Unlike Vygotsky, Durkheim is not primarily concerned with a process; he is emphasising the (social) power and objectivity of classifications, which, he argues, apply just as much to the relationship between science and common sense today as they did to the separation of the sacred and profane worlds of primitive societies.

In his recent book, Daniels (2000) points out that Vygotsky's analysis stresses both the distinctions between everyday and scientific concepts and their interdependence. However, while recognising their distinctive strengths, Vygotsky's primary emphasis is on the limitations of everyday concepts. For him, like common sense for Durkheim, everyday concepts lack any 'capacity for abstraction and generalisation' (p. 108) and fail to provide the learner with the resources to act in a voluntary manner. Although Vygotsky is never explicit about what he means by science, he clearly did not restrict its meaning to the natural sciences. Some commentators have suggested that as his examples usually refer either to Darwin's theory of evolution or to Marx; he must have favoured a Marxist interpretation of the term science. The next section, therefore locates Vygotsky's distinction between scientific and everyday concepts more broadly in a Marxist or dialectical materialist theory of knowledge.

\section{A Dialectical Interpretation of Vygotsky's Distinction Between Scientific and Everyday Concepts}

Although Vygotsky did not write specifically about methodology, an indication that he was thinking along dialectical lines is suggested in his reference to

The dialectial leap (as) ... not only a transition from matter that is incapable of sensation to matter that is capable of sensation, but a transition of sensation to thought. This implies that reality is reflected in consciousness in a qualitatively different way in thinking than it is in immediate sensation. (Vygotsky, 1987, p. 47) (my italics)

His distinction between thinking and sensation is itself an indication of the differences he emphasised between science and common sense. My concern is to explore how far a dialectical interpretation of Vygotsky's distinction can help us to overcome the problems of Durkheim's ahistorical approach to knowledge. 
Since Hegel, social theories such as Marxism and Pragmatism have tried to tackle the problem of knowledge being both objective and in history by linking knowledge to human purposes rather than treating it as being 'for its own sake' and independent of history. However, in seeking to avoid giving knowledge a spurious autonomy, these theories, as far as I can see, lead either to relativism or dogmatism. In the absence of a concept of knowledge or truth that is in some sense independent of its historical origins, judgements are unavoidably made on the basis of criteria that are treated as given and beyond argument. In Hegel's idealist dialectic, criteria for knowledge and truth were linked to the movement of Reason in history; in Marx's materialism, they were linked to the class struggle and in pragmatism to a demystified idealism that idolised a practical and instrumental view of science. This is not the place to rehearse the problems with dialectical approaches to truth except to state that they all too easily reduce to instrumentalism or the justification of "what is' in specific cases. Hegel stands apart from the others, not the least because he was less specific than Marx or the pragmatists about what Reason in history actually meant. At times he seemed to see the emerging nation state of his time as the embodiment of reason; however this provided just as problematic criteria of truth as those that were offered later by Marx and the pragmatists. If we do not have any independent concept of knowledge, dialectical logic seems to leave us in an untenable relativist position. It may be that Vygotsky was aware of some of the difficulties presented by dialectical approaches and that this explains why, although he was intrigued by them, the whole question of method remains undeveloped in his own writing. I shall now consider Engestrom's (1991) explicitly dialectical interpretation of Vygotsky. Engestrom's account makes clear what is involved in thinking about Vygotsky's distinction in the framework of dialectic logic and suggests why, for all its evocative power as critique, the dialectical method is unable to fulfill its promise as a theory for generating new knowledge [16]. This section of the paper draws substantially on Engestrom's excellent account.

Dialectical logic, whether applied to knowledge or human development generally, depends for its objectivity on its claims to know the future course of history [17]. Engestrom begins by pointing out that in contrast to other forms of logic, dialectical logic claims to be based on the actual movement of history, not on abstractions. It is this idea of scientific theory of historical change that offers the promise of solving the problem of the meaning of Vygotsky's 'scientific' concepts. Dialectics, Engestrom states, reverses the direction of conventional logic.

Instead of seeing 'concrete' phenomena as something sensually palpable and 'abstraction' as a conceptual or mentally constructed process, 'concrete' (things how they are') refers to the systemic interconnectedness of things. In other words, concrete phenomena are the outcome not the starting point of thinking. (p. 28, my italics)

From the perspective of the dialectical method, formal abstractions, such as those developed by Durkheim, can only separate arbitrary features of objects from their 'real' interconnections. In contrast, Vygotsky's scientific and everyday concepts, seen dialectically, are concrete abstractions that reflect and reconstruct the systemic and interconnected nature of the objects that they refer to.

In order to illustrate this argument, Engestrom refers to Marx and Engels' comparison between their concept of the proletariat as 'the most revolutionary class of bourgeois society - the gravedigger of capitalism' (p. 29) and the typical sociological definition of the working class as 'the most oppressed and passively suffering poverty-ridden class, capable, at best, only of a desperate hungry rebellion'. In other words, Engestrom states, the Marxist 
concept of the proletariat was the theoretical expression of the objective conditions of the working class.

The truth of this proposition is born out, according to the Russian philosopher Ilyenkov, "by the real transformation of the proletariat from a "class in itself" into a "class for itself", (quoted in Engestrom, 1991, p. 29).

We have, therefore, an example of Marx's materialist transformation of Hegel's dialectic or movement of Reason in history. Unfortunately history has, if it can be claimed to 'bear out' anything, born out the opposite to what Ilyenkov claimed. In an ironic twist, it can be argued that in forcing capitalism to reform, the proleteriat has succeeded in being its own grave-digger, not that of capitalism [18].

Engestrom again quotes Ilyenkov, who states that a dialectical concept

expresses a reality which, while being quite a particular phenomenon . . . is at the same time a genuinely universal element . . in all the other particular phenomena (p. 29).

It follows that the task of concept formation is to identify these genuine universal elements. Engestrom then asks the key question

how do (such genuine) concepts emerge in the first place?

To answer this question, he turns to three other Russian philosophers, Arsen'ev, Bibler and Kedrov, who argue that genuine concepts arise out of the interplay of forces involved in any productive activity. It follows that scientific concepts need not be limited to those developed and used within the historically formed activity called science.

From our standpoint, any ... concept is in its potentiality ... scientifictheoretical. (Arsen'ev et al., quoted in Engestrom, 1991, p. 31) (my italics)

Thus, everyday thinking has in principle the same theoretical potential as the consciously elaborated concepts of science. Engestrom quotes Ilyenkov as making a similar point when he asserts that

the universal laws of thought are the same both in scientific and so-called everyday thinking. (Ilyenkov, quoted in Engestrom, 1991b, p. 31)

The distinction between scientific and everyday concepts does not itself, therefore, provide the criteria for knowledge or the curriculum. If we follow Engestrom's analysis, it is only by setting Vygotsky's distinction within the framework of the dialectical movement of history and from this developing a set of methodological criteria for generating scientific concepts that the significance of his distinction emerges. The dialectic, as the quote from Ilyenkov implies, refers to the 'universal laws of thought', and applies not only to 'scientific and socalled everyday thinking', but to every field of knowledge.

Engestrom summarises the dialectical approach in a quote from the Russian psychologist, Davydov:

genuine concept formation ascends first from perceptually concrete phenomena to the substantial abstraction which expresses the genetically original inner contradiction of the system under scrutiny. It then proceeds to concrete generalization by deducing the various particular manifestations from this developmental basis. (Davydoff, quoted by Engestrom, 1991, p. 32) 
The problems with such an approach for curriculum designers is that (a) it is methodological not substantive, (b) it assumes the universal applicability of dialectic logic, not only as an account of the movement of history, but as a methodology for the generation of new knowledge in every field and as a theory of learning and teaching and hence a basis for the curriculum.

Hedegaard refers to Vygotsky's approach as 'a method of theoretical knowledge (that involves) relating concrete instances to general ideas ... and understanding generalities as concrete instances' (Hedegaard, 1999, p. 29). However it is far from clear what is distinctive about this 'method' or where the 'general ideas' come from. Later in the same paper, Hedegaard states that

The meaning of the concepts ... is dialectically formed through the concepts relations to each other. For example in the subject domain of evolution the concepts species and population define each other. (Hedegaard, 1999, p. 29)

Here the 'dialectical' method seems to lose its distinctiveness altogether; it merely describes the way evolutionary biologists define concepts in their field, just as chemists relate atomic structure and the periodicity of the elements. We are left with a method that is either too general to have any applicability or it involves assumptions which do not necessarily apply in specific fields. What then are the strengths of a dialectical interpretation of Vygotsky's approach for curriculum theory? First, it stresses the importance of a historical approach to the development of knowledge. Second, it attempts to hold together three processes that are inextricably linked in human history but are invariably treated as separate both in curriculum models and in research. These processes are: (i) the movement of history as the transformation of men's relationships with each other and with nature, (ii) the growth and development of knowledge, and (iii) the processes of learning and development. Third, it defines knowledge and therefore the curriculum in term of purposes not fixed notions of objectivity or 'knowledge for its own sake'.

However, as the earlier example of Hedegaard illustrated, a dialectical approach operates at too high a level of generality when it comes to identifying specific curriculum options. While it claims to be a critique of abstractions from the point of view of the real movement of history, it is in effect another abstraction claiming to be the development of historical reality. Furthermore, insofar as it over-emphasises 'method', even in the theoretical sense, it plays down the importance of concrete analyses. I am not aware of any examples of the dialectical method being applied other than retrospectively or leading to the generation of new knowledge in any field. It is difficult to envisage what kind of general rules could exist for identifying historically generative concepts in, for example, chemistry, literature and history, that go beyond the core concepts that would be identified by specialists in their fields. The rules of the dialectic are in practice, if not in theory, formal, not substantive. There is no distinct 'knowledge category' within the dialectic, so knowledge has to be 'imported' or assumed.

My conclusions are that a dialectical interpretation of Vygotsky's distinction between scientific and everyday concepts exposes its limitations but is valuable in reminding us of the non-givenness of categories such as science and knowledge and the historically changing boundaries which shape curricula. In the next section I draw on Durkheim's discussion of pragmatism (Durkheim, 1983) to suggest how Vygotsky's approach might be complemented by introducing the idea of knowledge as a distinctive category while retaining its historical origins. 


\section{Knowledge as a Distinctive Category: Durkheim's social realist approach}

In the previous section, I drew on Engestrom's account to locate Vygotsky's distinction between scientific and everyday concepts within the framework of dialectical logic. However, the dialectical method assumes a particular view of historical development and that knowledge can only be understood in terms of its consequences rather than as explanations located within frameworks of understanding shared by specialist communities. These assumptions mean that in effect a role for knowledge as a distinct category is denied and therefore such an approach cannot fulfil its claims to provide a generative theory of the curriculum. There are no good grounds for supposing that either the development of history or the generation of knowledge in different fields, or the process of acquisition of knowledge can be subsumed within the principles of the dialectical method, except in the most general and therefore, not very useful sense. As a result, approaches that rely on a dialectical method cannot avoid the implicit acceptance of some knowledge as given and taking as beyond question the generalising capacity of some concepts. The consequences of this, as in the case of how Vygotsky's ideas were used in the Soviet Block countries in the Stalinist era, were far from trivial [19].

Examples of the more substantive content of the dialectical method that are sometimes referred to are the inter-relatedness of concepts and the principle of contradiction. However, abstracted from the historicism of dialectical materialism, neither are distinctive; the former is familiar to systems theorists and the latter in functionalist social theory but expressed as unintended consequences. The question then is whether we are left with either the a-historical abstractions of Durkheim or a misplaced historicism that claims to know the course of history as the only alternatives to the conservatism of the principle of insularity or the relativism of hybridity. In the remainder of this section I will suggest that Durkheim later work on pragmatism does offer a basis for treating knowledge as a distinct but social category (in other words, that knowledge involves truth claims that can have varying degrees of autonomy from its social origins or context of acquisition). Secondly, I will argue that Durkheim's approach to the objectivity of knowledge is more complementary than antithetical to a modified dialectical interpretation of Vygotsky's ideas.

As Rytina and Loomis (1970) argue, although the content of Marxism and pragmatism are very different, the dialectical structure of the two theories, both of which have Hegelian roots, is remarkably similar. Both rejected the scholasticism of 'academic' philosophy in favour of fusing theory and practice. Both argue that the validity of knowledge and the objectivity of truth are practical questions to be judged in terms of human purposes and outcomes. Knowledge is valid for both Marxism and pragmatism if it serves the betterment of mankind (even though they differed profoundly about what that betterment might involve). Durkheim did not give much direct attention to Marxism, at least in his published work. However, he makes a sharp distinction between his view that religion has social origins and the Marxist idea that religion is no more than 'a translation into another language of the material foundation of society' (Durkheim, 1961, p. 471).

For Durkheim, although all social life bears the mark of its material foundation, collective consciousness is more than an epiphenomenonon-it has a life and an objectivity of its own. He was however much more concerned with pragmatism than marxism, for quite specific reasons [20].

Durkheim praised pragmatism for its heightened sense of human reality' (p. 111) in contrast to the pervasive idealism of other theories of the time. Durkheim, like the pragmatists, agreed that 'all that constitutes reason, its principles and categories, has been made in the course of history' 
However he was concerned that for pragmatism, truth and knowledge had no external compelling character; it had only practical utilitarian value. Truth and knowledge in any objective sense were, if pragmatism was right, at best useful instruments for organising every day life. Durkheim's view was that the objectivity of truth and knowledge (and morality) are real regardless of whether they are or are not perceived as useful. First, the objectivity of knowledge is necessary for orienting people to their collective existence in society. This is the well-known Durkheimian argument that in conditions of modernity, where social differentiation means that interdependence rather than similarity is the characteristic way in which people relate to each other, shared values have a key integrative role. In addition, however, Durkheim saw that the unique feature of both knowledge and truth is that they are compelling and that this obligatory character of knowledge was the major condition for the production of new knowledge - an insight often missed in contemporary sociology of science.

Durkheim argued that Pragmatism collapses truth into the sensations, instincts and the consciousness of individuals; in a similar way Marxist dialectics linked truth to the emancipation of the working class in history and in the Soviet era to the exigencies of Communist Party politics. For Durkheim, both Pragmatism and Marxism neglect the fundamental obligatory character of truth and knowledge that gives them their objectivity - the former replacing it with individual benefit, the latter with political power. Durkheim's conclusions are, first that the arguments for the objectivity of knowledge are social, not philosophical and second that knowledge relates to the causes of things, not their consequences. Causality for Durkheim, whether religious or scientific, has a conceptual and therefore a social basis [21].

Why is Durkheim's argument about knowledge so important for the curriculum? The answer goes back to an earlier point that I made about the differences between Durkheim and Vygotsky's views of the social origins of knowledge. I showed that Durkheim located the origins of theoretical knowledge in the shared religious beliefs of members of primitive societies. The significance of religious belief for Durkheim was not that it solved practical problems, but that it gave people a sense that they could not generate from experience, of who they were and where they were going. It also, for Durkheim, was the paradigmatic basis for all conceptual thought, including science. In contrast, Vygotsky locates the origins of science and other higher forms of thought in early man's search for food, building and shelter. For Vygotsky, religion, because it did not contribute to human development and therefore to the realisation of man's destiny, was unimportant and would wither away. The important knowledge developed by early man was what he acquired in appropriating nature. This difference underlies the social basis of the separate reality of knowledge as a distinct category and the fundamental separation of theoretical knowledge (originally religion) and common sense for Durkheim, and their equally fundamental integration for Vygotsky. Science, as the development and testing of unobservable, socially shared concepts, was not, for Vygotsky a distinct activity; it was an integral part of the way man appropriates nature in history. Hence, for Vygotsky, as a Marxist, epistemological questions about knowledge as a separate category distinct from practice did not exist; they were always resolved in practice, in the course of history. It follows that Vygotsky's distinction between scientific and common sense concepts was a contingent one to be overcome in practice and through learning. For Durkheim, the separation between theoretical knowledge and common sense was not contingent; it was real. The development of knowledge for Durkheim involved the progressive replacement of one kind of 'sacred' or theoretical knowledge (religion) by another (science). Hence he was able to argue for the necessary social basis of the differentiation of knowledge. 
The complementarity of the two theorists who appear to have reached different conclusions about the social basis of knowledge might be expressed as follows. Durkheim's sociology of knowledge neglects the technical appropriation of nature that was emphasised by Vygotsky, and cannot adequately account for how the unobservable concepts developed in early religions become the concepts of modern science with their power to transform the world. Vygotsky on the other hand, by locating the origins of knowledge in early man's practical activities, cannot adequately explain how these practical activities became transformed by theory. The two approaches can therefore be seen as complementary rather than mere critiques of each other. The curriculum must focus on both the social reality of knowledge that Durkheim stressed and the historical process of transforming knowledge and the world that was Vygotsky's priority. There is a sense in which Durkheim gives us the basis for a curriculum but no pedagogy whereas Vygotsky gives us a pedagogy but no curriculum.

\section{Conclusion}

This paper began by suggesting that there was a tension underlying the future development of the curriculum between the principle of insularity and the increasingly popular arguments in favour of hybridity and their opposing assumptions about the nature of curriculum and its relationship with everyday knowledge. It went on to examine Durkheim's social theory of knowledge and the arguments it provides for emphasising the distinctiveness of theoretical knowledge and the role of the curriculum in providing opportunities for people to acquire it. His arguments suggest that we should be cautious about blurring disciplinary and subject boundaries and weakening the specialist research and pedagogic communities associated with them. I suggested, however, that a Durkheimian analysis, in failing to emphasise the historical character of knowledge, can lead to a narrowly conservative view of knowledge as given. Furthermore, it is unable to take account of the wider social changes that shape both knowledge and the curriculum. To address these issues, I turned to the work of Vygotsky and in particular his distinction between scientific and everyday concepts. I discussed some of the significant similarities and differences between Durkheim and Vygotsky's ideas and how relate in part to their different interpretations of the social origins of thought in primitive societies. From a Marxist perspective (and therefore for Vygotsky), scientific and everyday concepts and their interrelations are part of man's attempts throughout history to transform the world. The paper draws on Engestrom's writing to look critically at the strengths and weaknesses of such an approach. In subsuming logic and knowledge into history, I suggest that it cannot account for the distinctive feature of our era- the exponential growth of knowledge and its capacity for transforming the world. Although knowledge is always a product of people's actions in history, at least since the 17 th century (and in some instances before), knowledge has transcended the contexts in which it was developed in ways which would have been inconceivable in earlier eras.

Knowledge, like truth and morality is inevitably external to learners and to those trying to create new knowledge. Hence, the significance of the boundaries and classifications between knowledge and common sense, which Durkheim emphasised. It follows that there is, I would argue, no alternative to what I will call a social realist [22] approach to knowledge and the curriculum. Such an approach is social because it recognises, with Marx, Durkheim and Vygotsky, the role of human agency in the production of knowledge. Knowledge can never be taken as given in any more than a temporary sense; it is always a part of history. Equally the approach to knowledge and the curriculum that I am arguing for is realist because it recognises the context-independent characteristics of knowledge and that the powerful discontinuities between knowledge and common sense are not some transient separation to 


\section{M. F. D. Young}

be progressively overcome, but the real conditions that enable us to gain knowledge about the world. Knowledge is socially and historically constructed, but it cannot be subsumed into the processes of historical and social construction; in other words, we make knowledge out of knowledge. At the same time, this 'reality' of knowledge is itself social in origin. Whereas recognising the sociality of knowledge and neglecting its objective reality can lapse into relativism or dogmatism, a focus on its objective reality without recognising its sociality can become little more than a justification for the status quo. A curriculum of the future needs to treat knowledge as a distinct and non-reducible element in the historical process in which people strive to overcome the circumstances in which they find themselves. In relation to the starting point of this paper, these circumstances refer to the making, remaking and crossing of boundaries between disciplines and between school and workplace or everyday knowledge. These boundaries can be both

prisons and stereotypes ... (and) ... tension points condensing the past and opening up possible futures. (Bernstein, 2000, p. xx)

However, seeing these tensions between the legacy of the past and the pressures of the future as a historical process is not enough. The recognition that knowledge has an objectivity and is not just a historical process is important for two reasons. The first is Durkheim's point that the externality of knowledge is a necessary condition for the creation and acquisition of new knowledge. The second reason is associated with the growth of science in the period since the Enlightenment. This does not require us to accept, as Durkheim and Marx believed, that a single common scientific method was emerging, which would gradually be extended in scope from the natural world to the social world. It does recognise, however, that rules, codes and values associated with different specialist traditions, which make widely accepted claims about knowledge and how it is generated and acquired, have been developed. A curriculum with any claim to be 'for the future' cannot avoid treating the knowledge that has emerged from such traditions and specialist communities as a category in its own right and endeavouring to ensure that learners have access to the rules for its acquisition and production.

The idea of truth as something external to individuals but social (and therefore essentially human) was a condition, Durkheim argued, both for the production of knowledge and for orienting us to our membership of society. For him, just as moral ideals are the norms for conduct, so truth is the norm for thought and, I would add, knowledge must be the norm for the curriculum.

The limitations of an approach that is over reliant on Durkheim is that it can easily become static. Knowledge in science as in all other fields, changes. The Marxist tradition of dialectics, which Vygotsky was associated with, rejected a static view of knowledge by putting its confidence not in knowledge but in history 'being on their side'. At least since the Enlightenment, it is knowledge not history that, for all its weaknesses, and more successfully in some fields than others, has been the better guarantee of truth. Knowledge has been established in disciplines, and most (although not all) cross- or multi-disciplinary discoveries have originated within the disciplines not external to them (although, sometimes as a result of people trying to break out of them). Hybridity is best seen as an attempt either to challenge disciplinary authority or accelerate the 'break outs'. The dialectical method, if broadly conceived, is an attempt to give a historical, transformative and purposive dimension to hybridity. Until two decades ago, dialectics was defended, among Marxists at least. However, although strong on aspirations and claims, it was always weak on substantive method or results. Hybridity has emerged in recent decades in response to economic pressures to overcome the separation of theory and practice. However, like the 
dialectic it has rarely provided the conditions for generating or acquiring new knowledge or concepts. When applied to the curriculum it collapses boundaries and limits the possibilities for the acquisition of new knowledge.

New knowledge and new curricula are generated when researchers or learners acquire and build on existing knowledge and concepts from specific fields and disciplines to make sense of or transform the world. Insularity and Durkheim's concept of the 'sacred' are suggestive ways of describing the structure of knowledge and its social basis. Hybridity stresses the historically contingent aspect of these structures without giving us much idea of where they are going or whether some structures are more contingent than others. Vygotsky's distinction between scientific and everyday concepts retains the distinction between theory and common sense that is found in Durkheim and suggests that the relationship between the two needs to be located pedagogically and historically and understood in relation to a broader notion of human purposes. His importance for curriculum theory is not, in my view, in his specific concepts. They are suggestive but either too general to be clear how they might be developed or, if used uncritically as in the soviet era, liable to abuse. His importance is rather in his heroic attempt to hold together the processes of learning and the generation of new knowledge which over-specialisation within the curriculum and within research communities has forced apart. Who are the globalisation theorists who are also theorists of pedagogy and the curriculum? I am sure Vygotsky would have been one if he were living today.

Correspondence: Michael Young, Institute of Education, Woburn Square, London, WC1H 0NR, UK.

\section{Acknowledgements}

I am most grateful to Michael Barnett, Visiting Professor of Physics, Imperial College of Science, Technology and Medicine, for drawing my attention to these extracts from the writing of Paul Valery, and their relevance to my argument. I am also grateful to my colleague Jan Derry for her helpful comments on earlier drafts of this paper.

\section{Notes}

[1] This paper is based on a paper presented at the 5th Congress of the International Society for Cultural Research and Activity Theory, Amsterdam, Vrjje Universiteit, 18-22 June, 2002.

[2] In practice those supporting hybridity tend to reject the possibility of such grounds.

[3] There are indications, in his last writings, that Vygotsky was aware of the need to deal specifically with the problem of knowledge. However it is unclear how he would have tackled it if he had lived longer.

[4] Interpreting and developing Durkheim's ideas was an explicit theme of Bernstein's relatively early work (Bernstein, 1971) and of his last book which included the important paper on vertical and horizontal knowledge structures (Bernstein, 2000)

[5] The social anthropologist, Robin Horton (1974) argues that Durkheim was somewhat ambivalent as to the extent to which the sacred/profane distinction survived in modern societies of his time.

[6] Durkheim did not concern himself with the potential, both between and within societies, for religion, to promote divisions rather than integration. 
[7] For example, whether or not they can be represented mathematically (Collins, 1998)

[8] It follows from Durkheim's argument that capacity for abstract thinking is a property of being a member of a society. It is not, as most theories of intelligence assume, an individual attribute that is distributed unevenly across the population.

[9] If expressed in the terms Durkheim used for analysing the social division of labour, the stratification of knowledge would be an example of what he referred to as the 'forced' division of labour (Durkheim, 1964). Whereas for Durkheim the 'forced' division of labour is a pathological state that only rarely occurs, in practice it is a familiar feature of most modern societies.

[10] As Daniels (2000) points out, there are also similarities between Vygotsky's analysis and Bernstein's distinction between vertical and horizontal knowledge structures.

[11] Durkheim died in 1918, just before Vygotsky was beginning his career as a psychologist.

[12] One example is when Vygotsky states that 'philosophically this argument (that logical thought and the need for knowledge of truth itself arises in the interaction between the consciousness of the child and the consciousness of others) is reminiscent of Durkheim'. (Vygotsky, 1987, p. 85)

[13] This may have been a tactical political decision, given that many Soviet writers at the time saw a reference to Durkheim as a sign of 'bourgeois revisionism'.

[14] Vygotsky's distinction is in fact less clear-cut than I have stated it. For him all experience is mediated. His distinction between theoretical and everyday concepts refers to the different form and content of the mediation by the two types of concept.

[15] At the same time, Vygotsky explicitly emphasises why this is no justification for not teaching grammar (op. cit, p. 100)

[16] There is of course a parallel with Marxism as a theory of society. Despite the loss of interest in Marxism since the 1980s, both among left wing political activists and within the academic community, it continues to offer a powerful if increasingly neglected critique of contemporary capitalism. On the other hand, few would still claim that it offers either an adequate theory of social transformation or a basis for generating non-capitalist alternatives.

[17] This can be seen as an oversimplification of Hegel's original idea of dialectic and more associated with the 'official' Marxism of the Soviet Union. However without some claims to be able to chart the future it is difficult to see what dialectical logic offers that is excluded by more traditional forms of logic.

[18] Unless one wants to claim, with Hardt and Negri (2001), that the anti-globalisation/ anti capitalist protesters are the successors to Marx's proleteriat.

[19] The soviet psychologist, L.V. Zankov invoked the authority of Vygotsky in developing the following didactic principles:

- High level of difficulty of the subject matter.

- Rapid pace of instruction.

- Leading role of theoretical knowledge.

- Conscious school work of pupils.

- Systematic and aim-targeted development of every pupil in the class.

Peter Gavora (Comenius University, Bratislava) informed me that the order (from Moscow) to implement these principles nearly crippled the Czechoslovak primary schools between 1970 and 1980 . 
[20] Although Durkheim was sympathetic to the pragmatism of James and Dewey as a form of sociological philosophy, he was worried about its links with idealist philosophy which was being popularised in France at the time by Bergson. Durkheim argued that the instrumentalist idea of truth associated with pragmatism could all too easily be used to undermine the credibility of science, by weakening its claim to objectivity.

[21] It was by demonstrating the conceptual and the social basis of causality that Durkheim was able to distinguish his approach to knowledge from empiricism and rationalism.

[22] In using this term I am suggesting no links with the tradition of social realism in art and cinema.

\section{References}

Bernstein, B. (1971) Class, Codes and Control (Vol 1), Routledge \& Kegan Paul, London.

Bernstein, B. (2000) Pedagogy, Symbolic Control and Identity, Rowman \& Littlefield, Lanham, MA.

Collins, R. (1998) The Sociology of Philosophies, Belknap Press, Cambridge, MA.

Daniels, H. (2001) Vygotsky and Pedagogy, RoutledgeFalmer, London.

Durkheim, E. (1961) The Elementary Forms of Religious Life, Collier Books, New York.

Durkheim, E. (1964) The Division of Labour in Society, Free Press, New York.

Durkheim, E. (1983) Pragmatism and Sociology, Cambridge University Press, Cambridge.

Engestrom, Y. (1991b) Learning by Expanding, http://lchc.ucsd.edu/MCA/Paper/Engestrom/ expanding/toc.htm

Gellner, E. (1992) Reason and Culture, Blackwell, Oxford.

Gibbons, M., Limoges, C., Nowotny, H., Schwartsman, S., Scott, P., \& Trow, M. (1994) The New Production of Knowledge, London, Sage.

Hardt, M \& Negri, A. (2001) Empire, Cambridge, MA, Harvard University Press.

HEDEGAARd, M. (1999) The influence of societal knowledge traditions on children's thinking and development. In: M. HedegaArd \& J. Lompscher (eds) Learning Activity and Development, Aarhus University Press, Aarhus, Denmark.

Horton, R. (1974) Levy-Bruhl, Durkheim and the scientific revolution. In: R. Horton \& R. Finnegan (eds) Modes of Thought, Faber, London.

Luria, A.R \& Vygotsky, L.S. (1992) Ape, Primitive Man and Child, Harvester Wheatsheaf, Hemel Hempstead, UK.

Moore, R. \& Young, M. (2001) Knowledge and the curriculum in the sociology of education: towards a re-conceptualisation, British Journal of Sociology of Education, 22, 4.

Muller, J. (2000) Reclaiming Knowledge, RoutledgeFalmer, London.

Reich, R. (1991) The Work of Nations, Simon and Schuster, London.

RYtina, J.H. \& LoOMis, C.P. (1970) Marxist dialectic: power as knowledge, American Sociological Review, 35, 2.

VAlerY, P. (1891) Letter to Andre Gide, 27 March 1891, Correspondence Gide-Valery, 72.

ValeRY, P. (1941) The rules of classic art teach us, Tel Quel, 11, 73.

VyGotsky, L.S. (1962) Thought and Language, MIT Press, Cambridge, MA.

Vygotsky, L.S. (1987) The Collected Works of L.S Vygotsky (Vol 1), Plenum Press, New York \& London.

WARD, S. (1996) Reconfiguring Truth, Rowman and Littlefield, Lanham, MA.

Young, M.F.D. (1998) The Curriculum of the Future, Falmer Press, London.

Young, M.F.D. (1971) Knowledge and Control: new directions for the sociology of education, London, Collier Macmillan. 